\title{
Hubungan Penggunaan Media Pembelajaran Audio Visual dengan Minat Peserta Didik pada Pembelajaran Pendidikan Agama Islam di SMAN 1 Bangkinang Kota
}

\author{
NAJMI HAYATI* \\ M. YUSUF AHMAD** \\ FEBRI HARIANTO***
}

* Fakultas Agama Islam ( FAI ) Universitas Islam Riau ( UIR) Jl. Kaharuddin Nasution No.113, Pekanbaru. Telepon (0761) 45005, Email : najmi_perdana@yahoo.co.id

** Fakultas Agama Islam (FAI) Universitas Islam Riau (UIR) Pekanbaru

Jl. Kaharuddin Nasution, No. 113, Perhentian Marpoyan Pekanbaru 28284. Hp. 081365542760

***Fakultas Agama Islam (FAI) Universitas Islam Riau (UIR) Pekanbaru

Jl. Kaharuddin Nasution, No. 113, Perhentian Marpoyan Pekanbaru 28284

\begin{abstract}
Abstrak: Media pembelajaran audio visual adalah media perantara yang penyerapannya melalui pandangan dan pendengaran sehingga membangun kondisi yang dapat membuat siswa mampu memperoleh pengetahuan, keterampilan, atau sikap yang dipergunakan untuk membantu tercapainya tujuan belajar. Minat adalah keinginan besar terhadap sesuatu yang terdiri dari berbagai perasaan serta pemusatan perhatian yang sengaja dan penuh kemauan yang mengarahkan individu pada suatu pilihan. Rumusan masalah yang di bahas dari penelitian ini adalah apakah ada hubungan penggunaan media pembelajaran audio visual dengan minat peserta didik pada pembelajaran pendidikan agama islam di SMAN 1 Bangkinang Kota. Berdasarkan rumusan masalah tersebut maka penelitian ini bertujuan untuk mengetahui hubungan penggunaan media pembelajaran audio visual dengan minat peserta didik pada pembelajaran pendidikan agama islam. Adapun manfaat dari penelitian ini bagi kepala sekolah untuk mengambil kebijakan agar guru mampu menggunakan media dalam proses pembelajaran terutama media audio visual pada materi tertentu sehingga dapat menumbuhkan minat peserta didik dalam proses pembelajaran. Jenis penelitian ini adalah korelasi (hubungan). Untuk memperoleh data dari penelitian ini, maka digunakan metode pengumpulan data melalui angket yang disebarkan kepada 77 responden. Berdasarkan hasil pengolahan dan analisis data yang telah penulis lakukan, maka diperoleh hasil dalam taraf "rendah". Hubungan tersebut dibuktikan dengan tingkat korelasi positif sebesar 0,284 olahan SPSS dan hasil rumus Korelasi Product Moment 0,28 , terletak diantara interval 0,20-0,399 kondisi tersebut berarti ditemukan adanya hubungan penggunaan media pembelajaran audio visual dengan minat peserta didik pada pembelajaran pendidikan agama islam. Jadi, $r_{\text {hitung }}>r_{\text {tabel }}$ $(0,28>0,277)$ dan juga $t_{\text {hitung }}>t_{\text {tabel }}(2,53>2,000)$ sehingga Ha diterima dan Ho ditolak.
\end{abstract}

Kata kunci: Media Pembelajaran, Audio Visual, Minat Peserta Didik 


\section{PENDAHULUAN}

Pendidikan merupakan dasar dalam memajukan suatu negara. Hal menjadikan pendidikan merupakan hal yang mendapat perhatian secara serius. Maka, untuk meningkatkan mutu pendidikan diperlukan tenaga-tenaga guru profesional yang mampu mendidik dengan menggunakan berbagai metode, strategi, teknik mengajar serta mampu menguasai dan menggunakan teknologi.

Guru adalah tenaga pendidik yang bertugas melakukan transfer informasi kepada siswa, dalam hal ini guru akan memberi suatu kemudahan dalam proses belajar mengajar yaitu menciptakan suasana kegiatan belajar yang menyenangkan, menetapkan materi apa yang akan dipelajari, bagaimana cara menyampaikan, media apa yang akan digunakan, dan hasil akhir yang dicapai siswa. Dari tugas inilah, seorang guru harus mampu menjadikan siswa menguasai seluruh materi yang ia sampaikan.

Materi pendidikan agama islam yang disampaikan oleh guru didalam kelas kurang dipahami oleh siswa karna dalam proses pembelajaran dikelas, guru lebih mendominasi pembelajaran dibandingkan siswa dan komunikasi pembelajaran hanya bersifat satu arah saja, dimana komunikasi hanya dari guru ke siswa dan tidak ada timbal baliknya, sehingga pada saat pembelajaran berlangsung siswa merasa cepat bosan dan hal ini yang menyebabkan siswa keluar masuk kelas kurang bersemangat, mengganggu teman lain yang sedang belajar. Jadi tampak bahwa, kurangnya minat siswa terhadap pembelajaran pendidikan agama islam dan hal ini perlu disikapi, oleh karna itu guru harus mampu membuat siswa betah berada didalam kelas dengan suatu alasan bahwa siswa merasa senang berada didalam kelas dan memfokuskan perhatian dalam artian memfokuskan pikiran siswa atas

14, No. 2, Oktober 2017 ISSN 1412-5382 materi yang sedang diterima atau sedang diajarkan, sebab dengan adanya konsentrasi belajar maka siswa dapat memahami dan menyerap lebih dalam atas pelajaran yang dia terima.

Perasaan senang dan konsentrasi merupakan bagian dari minat. Minat termasuk dalam ranah afektif yang dapat mempengaruhi hasil akhir yang akan dicapai oleh siswa. Minat merupakan rasa kecenderungan hati terhadap sesuatu hal atau aktivitas tanpa ada yang menyuruh, untuk menarik minat siswa maka diperlukan suatu cara atau tehnik mengajar salah satunya dengan menggunakan media pembelajaran.

Penggunaan media sebagai sumber belajar pada saat proses pembelajaran masih kurang, salah satu sumber belajar yang dapat digunakan oleh guru yaitu media audio visual yang diproyeksikan dengan infokus / LCD Projector. Media audio visual yang diproyeksikan dengan infokus/LCD Projector dapat mengaktifkan siswa, memudahkan penyampaian materi dalam proses pembelajaran dan menambah minat belajar siswa. Proses pembelajaran dikelas akan lebih efektif jika menggunakan media pembelajaran, karena media pembelajaran dengan berbasis teknologi memberikan dampak yang sangat positif bagi kemampuan dan kemauan siswa untuk mengikuti kegiatan pembelajaran.

Febliza dan Afdal (2015:50) menyatakan bahwa media audio visual adalah sebuah cara pembelajaran dengan menggunakan media yang mengandung unsur suara dan gambar, dimana dalam proses penyerapan materi melibatkan indra penglihatan dan indra pendengaran.

Dengan adanya media audio visual yang diproyeksikan dengan infokus / LCD Projector, guru langsung bisa memberikan bukti konkrit atas apa yang sedang diajarkan dengan harapan, siswa 
bisa melihat, membandingkan, memahami, mengingat dan membuktikan atas apa yang telah disampaikan guru kepadanya.

Menurut Slameto (2010:180) minat adalah rasa lebih suka dan rasa keterikatan pada suatu hal atau aktivitas, tanpa ada yang menyuruh. Minat pada dasarnya adalah penerimaan akan suatu hubungan antara diri sendiri dengan sesuatu di luar diri. Semakin kuat atau dekat hubungan tersebut, semakin besar minatnya.

Pada mulanya media hanya berfungsi sebagai alat bantu visual dalam belajar/mengajar, yaitu berupa sarana yang dapat memberikan pengalaman visual kepada peserta didik antara lain untuk mendorong motivasi belajar, memperjelas konsep yang abstrak, dan mempertinggi daya serap atau retensi belajar. Kemudian Miarso dalam bukunya mengatakan dengan masuknya pengaruh teknologi audio pada sekitar pertengahan abad ke-20 lahirlah peraga audio visual yang terutama menekankan penggunaan pengalaman yang konkrit untuk menghindarkan verbalisme (Febliza \& Afdal, 2015:43).

Dewasa ini, ketika ilmu pengetahuan dan teknologi berkembang sangat pesat, proses pembelajaran tidak lagi di monopoli oleh adanya kehadiran guru di dalam kelas. Siswa dapat belajar di mana dan kapan saja. Siswa bisa belajar apa saja sesuai dengan minat dan gaya belajar. Seorang desainer pembelajaran dituntut untuk dapat merancang pembelajaran dengan memanfaatkan berbagai jenis media dan sumber belajar yang sesuai agar proses pembelajaran berlangsung secara efektif dan efisien (Sanjaya, 2010:197-198).

Perkembangan ilmu pengetahuan dan teknologi semakin mendorong upaya-upaya pembaharuan dalam pemanfaatan hasil-hasil teknologi dalam proses belajar. Para guru dituntut agar mampu menggunakan alat-alat yang dapat disediakan oleh sekolah, dan tidak tertutup kemungkinan bahwa alat-alat tersebut sesuai dengan perkembangan dan tuntutan zaman. Guru sekurangkurangnya dapat menggunakan alat yang murah dan efisien yang meskipun sederhana dan bersahaja tetapi merupakan keharusan dalam upaya mencapai tujuan pengajaran yang diharapkan. Disamping mampu menggunakan alat-alat yang tersedia, guru juga dituntut untuk dapat mengembangkan keterampilan membuat media pengajaran yang akan digunakannya apabila media tersebut belum tersedia (Arsyad, 2011:2).

Menurut Febliza \& Afdal (2015:4344), perkembangan zaman saat ini yang begitu pesat, membuat dunia teknologi menjadi tambah modern. Karena itulah muncul berbagai media pembelajaran yang dapat mendukung suatu proses belajar mengajar. Salah satu media yang mengalami perkembangan adalah media audio visual.

Berdasarkan studi pendahuluan penulis melihat bahwa guru PAI SMAN 1 Bangkinang Kota pada umumnya sudah memiliki pengetahuan tentang penggunaan media dalam proses pembelajaran, ini dapat dilihat dari latar belakang pendidikan, pada umumnya Sarjana (S1) Keguruan. Ini berarti mereka sudah mempelajari tentang penggunaan media pembelajaran. Selain itu SMAN 1 Bangkinang Kota merupakan sekolah Negeri terfavorit dan terletak di tengah Kota Bangkinang. Pemerintah Daerah memperhatikan sarana dan prasarana yang ada di sekolah tersebut.

Sayangnya, walaupun saat pembelajaran guru sudah menggunakan media infokus/ LCD Projector, akan tetapi kurang menarik minat peserta didik dalam belajar. Akhirnya, setelah penulis memperhatikan dengan seksama, terdapat beberapa gejalagejala terjadi, diantaranya: (1) Siswa di 
dalam pembelajaran jarang menggunakan media audio visual padahal media sudah disediakan pihak sekolah; (2) Sebagian siswa masih kurang memahami cara belajar di dalam penggunaan media audio visual; dan (3) Sebagian guru telah menggunakan media dalam pembelajaran tatapi masih monoton dan kurang kreatif dalam menarik minat peserta didik dalam proses pembelajaran.

Berdasarkan dari gejala-gejala diatas maka penulis mencoba alternatif pembelajaran yang lain, salah satunya dengan menggunakan media audio visual yang diproyeksikan dengan infokus atau LCD Projector untuk meningkatkan minat peserta didik. Dari uraian tersebut, peneliti melakukan penelitian dengan judul : "Hubungan Penggunaan Media Pembelajaran Audio Visual Dengan Minat Peserta Didik Pada Pembelajaran Pendidikan Agama Islam Di SMAN 1 Bangkinang Kota".

Berdasarkan latar belakang masalah yang telah dikemukakan di atas, maka penulis membatasi masalah "Hubungan Penggunaan Media Pembelajaran Audio Visual Dengan Minat Peserta Didik Pada Pembelajaran Pendidikan Agama Islam Di SMAN 1 Bangkinang". Adapun perumusan masalah pada penelitian ini adalah "Apakah Ada Hubungan Penggunaan Media Pembelajaran Audio Visual Dengan Minat Peserta Didik Pada Pembelajaran Pendidikan Agama Islam Di SMAN 1 Bangkinang Kota"? Sedangkan tujuan penelitian ini adalah untuk mengetahui "Hubungan Penggunaan Media Pembelajaran Audio Visual Dengan Minat Peserta Didik Pada Pembelajaran Pendidikan Agama Islam Di SMAN 1 Bangkinang Kota".

\section{KONSEP TEORI}

\section{Media Pembelajaran Audio Visual}

163

14, No. 2, Oktober 2017 ISSN 1412-5382
Menurut Azhar Arsyad (2011:3) kata media berasal dari bahasa Latin medius yang secara harfiah berarti 'tengah' atau 'pengantar'. Dalam bahasa Arab, media adalah perantara (وسائل) atau pengantar pesan dari pengirim kepada penerima pesan.

Dalam kamus besar bahasa Indonesia media berarti alat; alat (sarana) komunikasi seperti Koran, majalah, radio, televisi, film, poster dan spanduk (KBBI, 2008:892).

Arsyad (2011:3) batasan lain telah pula dikemukakan oleh para ahli yang sebagian di antaranya akan diberikan berikut ini. AECT (Association of Education and Communication Technology, 1997) memberi batasan tentang media sebagai segala bentuk dan saluran yang digunakan untuk menyampaikan pesan atau informasi.

National Education Assosiation (NEA) dalam Nunuk Suryani \& Leo Agung (2012:135) memberikan batasan media sebagai bentuk-bentuk komunikasi baik tercetak, audio visual, serta peralatannya.

Menurut Arsyad (2011:3), secara khusus pengertian media dalam proses belajar mengajar cenderung diartikan sebagai alat-alat grafis, photografis, atau elektronis untuk menangkap, memproses, dan menyusun kembali informasi visual atau verbal.

Gerlach dalam Wina Sanjaya (2010:204-205) secara umum media itu meliputi orang, bahan, peralatan atau kegiatan yang menciptakan kondisi yang memungkinkan siswa memperoleh pengetahuan, keterampilan, dan sikap.

Dari beberapa batasan di atas maka dapat disimpulkan bahwa media merupakan segala sesuatu yang dapat dipergunakan untuk menyalurkan pesan dan dapat merangsang pikiran, membangkitkan semangat, perhatian, dan kemauan siswa sehingga dapat mendorong terjadinya proses pembelajaran pada diri siswa. 
Pembelajaran merupakan bentuk jamak dari kata belajar yang mempunyai kata dasar ajar. Ajar menurut KBBI petunjuk yang diberikan kepada orang supaya diketahui (diturut), belajar merupakan suatu usaha untuk memperoleh kepandaian/ilmu. Istilah pembelajaran lebih menggambarkan usaha guru/pendidik untuk membuat para peserta didik melakukan proses belajar (Suryani \& Agung, 2012:136).

Fadlillah (2014:131) berpendapat bahwa istilah pembelajaran berasal dari kata belajar, yaitu suatu aktivitas atau suatu proses untuk memperoleh pengetahuan, meningkatkan keterampilan, memperbaiki perilaku, sikap, dan mengukuhkan kepribadian.

Suyitno dalam Hamdani (2011:7172) pembelajaran secara umum adalah kegiatan yang dilakukan guru sehingga tingkah laku siswa berubah ke arah yang lebih baik. Pembelajaran adalah upaya guru menciptakan iklim dan pelayanan terhadap kemampuan, potensi, minat, bakat, dan kebutuhan siswa yang amat beragam agar terjadi interaksi optimal antara guru dan siswa serta antar siswa.

Dari beberapa pengertian di atas dapat dipahami bahwa dikatakan pembelajaran apabila terjadi interaksi antara peserta didik dengan pendidik, serta diikuti dengan sumber belajar yang memadai yang terdapat dalam lingkungan belajar sehingga terjadi perilaku-perilaku tertentu.

Selanjutnya, Suryani dan Agung (2012:137) menyatakan bahwa media pembelajaran adalah bahan, alat, atau teknik yang digunakan dalam kegiatan belajar-mengajar dengan maksud agar proses interaksi komunikasi pendidikan antara guru dan siswa dapat berlangsung secara tepat guna dan berdaya guna.

Miarso dalam Fadlillah (2014:206) menyebutkan bahwa media pembelajaran ialah segala sesuatu yang digunakan untuk menyalurkan pesan serta dapat merangsang pikiran, perasaan, perhatian, dan kemauan si pelajar sehingga dapat mendorong terjadinya proses belajar yang disengaja, bertujuan, dan terkendali.

Dari beberapa definisi di atas dapat disimpulkan bahwa media pembelajaran adalah segala sesuatu yang dapat digunakan untuk menyalurkan pesan dari pengirim ke penerima sehingga merangsang pikiran, perasaan, perhatian, dan minat serta kemauan peserta didik sedemikian rupa sehingga proses belajar terjadi dalam rangka mencapai tujuan pembelajaran secara efektif.

Dalam Kamus Besar Bahasa Indonesia audio visual berarti bersifat dapat didengar dan dilihat; alat pandang dengar (KBBI, 2008:100).

Menurut Hamdani (2011:249) sesuai dengan namanya, media ini merupakan kombinasi audio dan visual atau bisa disebut media pandangdengar. Audio visual akan menjadikan penyajian bahan ajar kepada siswa semakin lengkap dan optimal.

Sanjaya (2010:211) berpendapat media audio visual, yaitu media yang selain mengandung unsur suara juga mengandung unsur gambar yang dapat dilihat, seperti rekaman video, berbagai ukuran film, slide suara, dan lain sebagainya.

Febliza dan Zul (2015:50) mengatakan pembelajaran dengan menggunakan media Audio-visual adalah sebuah cara pembelajaran dengan menggunakan media yang mengandung unsur suara dan gambar, dimana dalam proses penyerapan materi melibatkan indra penglihatan dan indra pendengaran.

Melihat perincian pengertian komponen-komponen yang ada, maka dapat disimpulkan bahwa media pembelajaran audio visual adalah media perantara yang penyerapannya melalui pandangan dan pendengaran sehingga 
membangun kondisi yang dapat membuat siswa mampu memperoleh pengetahuan, keterampilan, atau sikap yang dipergunakan untuk membantu tercapainya tujuan belajar.

\section{Hakikat Media}

Oemar Hamalik (1994) dalam Azhar Arsyad (2011:15) mengemukakan bahwa pemakaian media pembelajaran dalam proses belajar mengajar dapat membangkitkan keinginan dan minat baru siswa, membangkitkan motivasi dan rangsangan kegiatan belajar dan bahkan membawa pengaruh-pengaruh psikologis terhadap siswa.

Media merupakan salah satu ide yang sangat tepat dalam menyiasati kejenuhan peserta didik karena pembelajaran dengan menggunakan media dirasa cukup efektif dan dapat menggairahkan semangat mereka dalam mengikuti jalannya proses belajar mengajar. Menurut Yushadi Miarso (2011:458-460) media audio visual mempunyai berbagai macam fungsi, seperti yang disebutkan sebagai berikut: (a) Media mampu memberikan rangsangan yang bervariasi pada otak, sehingga otak dapat berfungsi secara optimal; (b) Media dapat mengatasi keterbatasan pengalaman yang dimiliki oleh para siswa; (c) Media dapat melampaui batas ruang kelas; (d) Media memungkinkan adanya interaksi langsung antara siswa dan lingkungannya; (e) Media menghasilkan keseragaman pengamatan; (f) Media membangkitkan keinginan dan minat baru; (g) Media membangkitkan motivasi dan merangsang untuk belajar; (h) Media memberikan pengalaman yang integral dari sesuatu yang konkret maupun abstrak; (i) Media memberikan kesempatan siswa untuk belajar mandiri, pada tempat dan waktu serta kecepatan yang ditentukan sendiri; (j) Media meningkatkan kemampuan 165

14, No. 2, Oktober 2017 ISSN 1412-5382 keterbacaan baru (new literacy), yaitu kemampuan untuk membedakan dan menafsirkan objek, tindakan, dan lambang yang tampak, baik yang alami maupun buatan manusia, yang terdapat dalam lingkungan; (k) Media mampu meningkatkan efek sosialisasi, yaitu dengan meningkatnya kesadaran akan dunia sekitar; dan (l) Media dapat meningkatkan kemampuan ekspresi diri dosen maupun mahasiswa.

\section{Jenis Media Audio Visual}

Menurut Syaiful Bahri Djamarah dan Aswan Zain media audio visual adalah media yang mempunyai unsur suara dan unsur gambar. Jenis media ini mempunyai kemampuan yang lebih baik, karena meliputi kedua jenis media yang pertama dan kedua. Media ini dibagi lagi ke dalam: (a) Audio Visual Diam, yaitu media yang menampilkan suara dan gambar diam seperti film bingkai suara (sound slides), film rangkai suara, cetak suara; dan (b) Audio Visual Gerak, yaitu media yang dapat menampilkan unsur suara dan gambar yang bergerak seperti film suara dan video cassette.

Adapun pembagian lain dari media ini adalah: (a) Audio Visual Murni, yaitu baik unsur suara maupun unsur gambar berasal dari satu sumber seperti film video-cassette; dan (b) Audio Visual Tidak Murni, yaitu yang unsur suara dan unsur gambarnya berasal dari sumber yang berbeda, misalnya film bingkai suara yang unsur suaranya bersumber dari tape recorder. Contohnya lainnya adalah film strip suara dan cetak suara.

Pada penelitian ini, materi pelajaran yang disampaikan melalui media audio visual dengan menggunakan LCD Projector atau Infokus. Sutrisno \& Suherman (2007:4243) LCD (Liquid Crystal Display) Projector adalah alat bantu presentasi multimedia yang dapat menampilkan 
gambar dan suara. Alat bantu presentasi ini digunakan bersama-sama dengan alat lain seperti computer dan compact disk. Tetapi, alat presentasi ini juga bisa digunakan secara mandiri, artinya tidak digabungkan dengan alat lain apabila LCD Projector yang digunakan sudah mempunyai fasilitas memori.

\section{Langkah-langkah Penggunaan Media}

Menurut Syaiful Bahri Djamarah \& Aswan Zain (2013:136), ada 6 langkah yang bisa di tempuh guru pada waktu ia mengajar dengan mempergunakan alat peraga. Langkah-langkah itu ialah: (1) Merumuskan tujuan pengajaran dengan memanfaatkan media; (2) Persiapan guru. Pada fase ini guru memilih dan menetapkan media mana yang akan dimanfaatkan guna mencapai tujuan; (3) Persiapan kelas. Pada fase ini siswa atau kelas harus mempunyai persiapan, sebelum mereka menerima pelajaran dengan menggunakan media. Guru harus dapat memotivasi mereka agar dapat menilai, mengantisipasi, menghayati pelajaran dengan menggunakan media pengajaran; (4) Langkah penyajian pelajaran dan pemanfaatan media. Pada fase ini Penyajian bahan pelajaran dengan memanfaatkan media pengajaran. Keahlian guru dituntut di sini. Media diperbantukan oleh guru untuk membantu tugasnya menjelaskan bahan pelajaran. Media dikembangkan penggunaanya untuk keefektifan dan efisiensi pencapaian tujuan; (5) Langkah kegiatan belajar siswa. Pada fase ini siswa belajar dengan memanfaatkan media pengajaran. Pemanfaatan media di sini bisa siswa sendiri yang mempraktikkannya atau pun guru langsung memanfaatkannya, baik di kelas atau di luar kelas; dan (6) Langkah evaluasi pelajaran. Pada langkah ini kegiatan belajar dievaluasi, sampai sejauh mana tujuan pengajaran tercapai, yang sekaligus dapat dinilai sejauh mana pengaruh media sebagai alat bantu dapat menunjang keberhasilan proses belajar siswa. Hasil evaluasi dapat dijadikan dasar atau bahan bagi proses belajar berikutnya.

\section{Konsep Minat}

Menurut Slameto (2010:180) minat adalah rasa lebih suka dan rasa keterikatan pada suatu hal atau aktivitas, tanpa ada yang menyuruh. Minat pada dasarnya adalah penerimaan akan suatu hubungan antara diri sendiri dengan sesuatu di luar diri. Semakin kuat atau dekat hubungan tersebut, semakin besar minatnya.

Dalam kamus besar bahasa Indonesia minat berarti kecenderungan hati yang tinggi terhadap sesuatu; gairah; keinginan (KBBI, 2008:916). Djaali (2007:121) minat tidak di bawa sejak lahir, melainkan diperoleh kemudian.

Minat ialah suatu dorongan yang menyebabkan terikatnya perhatian individu pada objek tertentu seperti pekerjaan, pelajaran, benda, dan orang. Minat berhubungan dengan aspek kognitif, afektif, dan motorik dan merupakan sumber motivasi untuk melakukan apa yang diinginkan. Minat berhubungan dengan sesuatu yang menguntungkan dan dapat menimbulkan kepuasan bagi dirinya (Jahja, 2011:63).

Hamdani (2011:140) minat menurut para ahli psikologi adalah suatu kecenderungan untuk selalu memerhatikan dan mengingat sesuatu secara terus-menerus. Minat ini erat kaitannya dengan perasaan, terutama perasaan senang. Dapat dikatakan minat itu terjadi karena perasaan senang pada sesuatu.

Dari berbagai definisi di atas dapat disimpulkan bahwa minat adalah keinginan besar terhadap sesuatu yang 
terdiri dari berbagai perasaan serta pemusatan perhatian yang sengaja dan penuh kemauan yang mengarahkan individu pada suatu pilihan.

\section{Unsur-unsur Minat}

$\begin{array}{ccr}\text { Menurut } & \text { Muhibbin } & \begin{array}{r}\text { Syah } \\ \text { (2007:151) }\end{array} \text { minat } \\ \text { berarti }\end{array}$ kecenderungan dan kegairahan yang tinggi atau keinginan yang besar terhadap sesuatu. Menurut Rebber (1988), ketergantungannya banyak pada faktor-faktor internal lainnya, seperti perhatian, keingin tahuan atau kemauan, motivasi, kebutuhan dan perasaan.

\section{Perasaan}

Abdul Rahman Shaleh (2008:150) pada umumnya, perbuatan kita seharihari disertai oleh perasaan-perasaan tertentu, yaitu perasaan senang atau tidak senang. Perasaan senang atau perasaan tidak senang yang selalu menyertai perbuatan kita sehari-hari disebut warna efektif. Warna efektif ini kadang-kadang kuat, kadang-kadang lemah atau samar-samar saja.

Unsur yang tak kalah pentingnya adalah perasaan dari anak didik terhadap pelajaran yang diajarkan oleh gurunya. Sumadi Suryabrata (2005:66) perasaan didefinisikan sebagai gejala psikis yang bersifat subjektif yang umumnya berhubungan dengan gejalagejala mengenal dan dialami dalam kualitas senang atau tidak dalam berbagai taraf.

Menurut Baharuddin (2007:135) perasaan, adakalanya berwujud senang atau tidak senang, simpati atau antipasti, suka atau benci, gembira atau sedih dan lain-lain. Bagi individu, apa yang menyenangkan atau yang disukai, tentu akan mendorongnya untuk mendekati atau mencapainya. Sedangkan yang tidak disukai, tentu akan mendorongnya untuk menjauhi atau menghindarinya.

167

14, No. 2, Oktober 2017 ISSN 1412-5382
Jadi perasaan adalah suatu keadaan kerohanian atau peristiwa kejiwaan yang kita alami dengan senang atau tidak senang dalam hubungan dengan peristiwa mengenal dan bersifat subyektif.

\section{Perhatian \\ Perhatian mempunyai peranan penting dalam kegiatan belajar. Perhatian terhadap pelajaran akan timbul pada siswa apabila bahan pelajaran itu dirasakan sebagai sesuatu yang dibutuhkan, diperlukan untuk belajar lebih lanjut atau diperlukan dalam kehidupan sehari-hari, akan membangkitkan motivasi untuk mempelajarinya (Rusman, et.al.} 2012:22).

Sriyanti (2013: 110-111) berpendapat bahwa perhatian merupakan pemusatan seluruh aktivitas individu terhadap suatu objek atau sekumpulan objek atau perangsang. Tingkat yang lebih tinggi dari perhatian adalah minat dan konsentrasi. Seseorang yang sedang memperhatikan sesuatu, maka aktivitas individu tersebut dicurahkan atau dipusatkan dan dikonsentrasikan pada objek yang sedang diperhatikan.

Menurut Slameto (2010:105) perhatian adalah kegiatan yang dilakukan seseorang dalam hubungannya dengan pemilihan rangsangan yang datang dari lingkungannya.

Gazali dalam Slameto (2010:56) perhatian keaktifan jiwa yang dipertinggi, itu pun semata-mata tertuju kepada satu obyek (benda/hal) atau sekumpulan objek.

Sumadi Suryabrata (2005:14) mengatakan perhatian adalah pemusatan tenaga psikis yang tertuju pada suatu obyek.

Menurut Zakiah Daradjat (1995:136) perhatian memegang Jurnal Al-hikmah Vol. 
peranan penting dalam proses belajar. Thomas M. Risk mengemukakan: "no learning takes place without attention" pembelajaran tidak akan terjadi tanpa adanya perhatian.

Perhatian adalah merupakan reaksi umum dari organisme dan kesadaran yang menyebabkan bertambahnya aktivitas, daya konsentrasi dan pembatasan kesadaran terhadap suatu objek. Perhatian merupakan keaktifan jiwa yang dipertinggi. Jiwa semata-mata tertuju kepada suatu objek (benda atau hal) atau sekumpulan objek-objek. Perhatian sangat dipengaruhi oleh perasaan dan suasana hati seseorang dan ditentukan oleh kemauan. Dapat disimpulkan bahwa perhatian adalah keaktifan jiwa yang diarahkan kepada suatu objek, baik di dalam maupun di luar dirinya (Daulay, 2014:156-157).

Dari beberapa pendapat di atas, dapat disimpulkan bahwa perhatian adalah pemusatan tenaga psikis yang tertuju pada suatu objek yang datang dari dalam dan dari luar individu.

\section{Motivasi}

Abdul Rahman Shaleh (2008:178) istilah motivasi baru digunakan sejak awal abad ke- XX. Selama beratus-ratus tahun, manusia dipandang sebagai makhluk rasional dan intelek yang memilih tujuan dan menentukan sederet perbuatan secara bebas. Nalarlah yang menentukan apa yang dilakukan manusia.

Menurut Suyono dan Hariyanto (2015:183) motivasi didefinisikan sebagai faktor-faktor internal maupun eksternal yang mendorong keinginan dan energi manusia untuk secara kontinyu menaruh minat dan perhatian terhadap pekerjaan, peranannya, atau kepada suatu subjek tertentu, serta memberikan upaya yang sungguhsungguh dan persisten dalam mencapai tujuan-tujuan tersebut. Dari definisi ini jelas ada relasi positif antara motivasi, minat, dan perhatian.

Abdul Rahman Shaleh (2008:182) motivasi dapat didefinisikan dengan segala sesuatu yang menjadi pendorong tingkah laku yang menuntut atau mendorong seseorang untuk memenuhi kebutuhan. Pada titik ini, motivasi menjadi daya penggerak perilaku (the energizer) sekaligus menjadi penentu (determinan) perilaku.

Menurut Najati dalam Daulay (2014:155), motivasi adalah kekuatan penggerak yang membangkitkan aktivitas pada makhluk hidup dan menimbulkan tingkah laku serta mengarahkan menuju tujuan tertentu. Motivasi memiliki tiga komponen pokok, yaitu menggerakkan, mengarahkan, dan menopang.

Motivasi dapat juga dikatakan serangkaian usaha untuk menyediakan kondisi-kondisi tertentu, sehingga seseorang mau dan ingin melakukan sesuatu, dan bila ia tidak suka, maka akan berusaha untuk meniadakan atau mengelakkan perasaan tidak suka itu. Jadi motivasi itu dapat dirangsang oleh faktor dari luar tetapi motivasi itu adalah tumbuh di dalam diri seseorang.

Persoalan motivasi ini, dapat juga dikaitkan dengan persoalan minat. Minat diartikan sebagai suatu kondisi yang terjadi apabila seseorang melihat ciri-ciri atau arti sementara situasi yang dihubungkan dengan keinginankeinginan atau kebutuhankebutuhannya sendiri. Oleh karena itu, apa yang dilihat seseorang sudah tentu akan membangkitkan minatnya sejauh apa yang dilihat itu mempunyai hubungan dengan kepentingannya sendiri (Sardiman, 2012:75-76).

Dari beberapa pendapat di atas jadi motivasi adalah sebagai suatu pendorong yang mengubah energi dalam diri seseorang ke dalam bentuk 
aktivitas nyata untuk mencapai tujuan tertentu.

Adapun penelitian terdahulu yang memiliki relevansi terhadap penelitian ini adalah: (1) Hubungan Penggunaan Media Pembelajaran Terhadap Hasil Belajar Pendidikan Agama Islam Di SMK Kansai Pekanbaru, pada tahun 2015. Penelitian di atas dilakukan oleh Utami Restimela Mahasiswi Fakultas Agama Islam Universitas Islam Riau, tahun 2015. Adapun hasil penelitian tersebut adalah bahwa tingkat hubungan Penggunaan Media Pembelajaran Terhadap Hasil Belajar Pendidikan Agama Islam di SMK Kansai Pekanbaru di nyatakan dalam tingkat korelasi positif sebesar 0,65 ( $\mathrm{r}=0,65)$. Berdasrkan $r_{\text {table, dapat dianalisa bahwa }}$ $\left(\mathrm{r}_{0}\right)$ lebih besar dari $\left(\mathrm{r}_{\mathrm{t}}\right)$, pada level 5\% dan $1 \%$ yaitu $0,381<0,652>0,449$. Sehingga dapat disimpulkan bahwa $\mathrm{H}_{\mathrm{a}}$ diterima dan $\mathrm{H}_{0}$ ditolak. Kondisi tersebut berarti terdapat hubungan yang kuat antara Penggunaan Media Pembelajaran Terhadap Hasil Belajar Siswa; (2) Penggunaan Media Audio Visual Untuk Meningkatkan Hasil Belajar Siswa Kelas X.A Pada Mata Pelajaran Ekonomi Di MA. Ummatan Wasathan Pesantren Teknologi Riau Jalan Lintas Timur Km.22 Pekanbaru, Pada Tahun 2009/2010. Penelitian di atas dilakukan oleh Yuliarti Mahasiswi Fakultas Ekonomi Universitas Islam Riau, tahun 2009/2010. Adapun hasil penelitian tersebut adalah penelitian ini dilakukan dengan tujuan untuk mengetahui peningkatan hasil belajar ekonomi siswa kelas XA MA.Ummatan Wasathan Pesantren Teknologi Riau melalui penggunaan media audio visual. Dari hasil penelitian ini diperoleh hasil bahwa terjadi peningkatan hasil belajar siswa kelas XA MA. Ummatan Wasathan Pesantren Teknologi Riau dari siklus I ke siklus II. Pada siklus I ketuntasan belajar siswa yang dilihat dari nilai ulangan rata-ratanya yaitu $81,90 \%$ dengan

169

14, No. 2, Oktober 2017 ISSN 1412-5382 kategori baik dan pada siklus II rata-rata nilai ulangan meningkat menjadi 91,90\% dengan kategori baik sekali. Dengan penggunaan media audio visual dalam proses belajar mengajar memicu semangat siswa untuk lebih baik; dan

(3) Pengaruh Penggunaan Media Audio Visual Terhadap Hasil Belajar MTK Siawa Kelas VIII SMPN 1 Duri, Pada Tahun 2012/2013. Penelitian di atas dilakukan oleh Leyri Okni Mahasiswi Fakultas Matematika Universitas Islam Riau, Tahun 2012/2013. Adapun hasil penelitian tersebut adalah dari penelitian yang dilakukan dengan menggunakan media audio visual pada siswa kelas VIII SMPN I Duri tahun ajaran 2012/2013 pada pokok bahasan kubus dan balok menunjukkan terdapatnya peningkatan hasil belajar siswa. Dari penelitian di dapat $t_{\text {hitung }}=3,52$ dan ini lebih besar dari $\mathrm{t}_{\text {tabel }}=1,70$. Jadi $\mathrm{H}_{0}: \mu_{1}=\mu_{2}$ ditolak dan $\mathrm{H}_{1:} \mu_{1} \neq \mu_{2}$ diterima. Berarti hasil belajar kelas eksperimen yaitu pembelajaran menggunakan pembelajaran konvensional. Dengan kata lain, terdapat pengaruh yang signifikan pada penggunaan media audio visual terhadap hasil belajar matematika siswa kelas VIII SMPN 1 Duri tahun ajaran 2012/2013.

Persamaan dan perbedaan penelitian yang akan penulis lakukan dengan penelitian di atas. Persamaannya terletak pada variabel $\mathrm{X}$ yang samasama menggunakan media audio visual sedangkan perbedaannya terletak pada variabel $Y$ yang mana pada penelitian yang relevan menggunakan hasil belajar siswa sedangkan penelitian yang penulis lakukan dengan variabel Y minat peserta didik dan juga tempat penelitiannya.

Selanjutnya, pada penelitian ini, hipotesis yang penulis tetapkan adalah :

Ha : Ada hubungan penggunaan media pembelajaran audio visual dengan minat siswa SMA Negeri 1 Bangkinang.

$$
\text { Jurnal Al-hikmah Vol. }
$$


Ho: Tidak ada hubungan penggunaan media pembelajaran audio visual dengan minat siswa SMA Negeri 1 Bangkinang.

\section{METODE}

Jenis penelitian yang digunakan dalam penelitian ini adalah penelitian korelasi. Jenis penelitian korelasi dapat diartikan sebagai penelitian yang berfungsi untuk mencari hubungan/pengaruh antara dua fenomena atau dapat juga disebut Probelma Korelasi (Dairi, 2013:30).

Penelitian dilaksanakan di SMAN 1 Bangkinang Kota, Kelurahan Langgini, Kecamatan Bangkinang, Kabupaten Kampar. Peneliti memilih lokasi penelitian ini, karena lokasi penelitian dekat dan mudah dijangkau peneliti. Penelitian ini dilaksanakan selama 4 bulan (sejak Januari 2016 sampai April 2016).

Subjek dalam penelitian ini adalah siswa kelas X SMAN 1 Bangkinang Kota, sedangkan objek dalam penelitian ini adalah hubungan penggunaan media pembelajaran audio visual dengan minat peserta didik pada pembelajaran pendidikan agama islam.

Adapun yang menjadi populasi dalam penelitian ini adalah siswa kelas $\mathrm{X}$ SMAN 1 Bangkinang Kota yang berjumlah 375 orang. Karena jumlahnya lebih dari 100 orang, maka tidak seluruh populasi yang penulis teliti. Penulis mengambil sampel $21 \%$ dari 375 orang yaitu 77 orang. Pengambilan jumlah ini berdasarkan pendapat Riduwan dan Akdon bahwa jika jumlah subjeknya besar dapat diambil sampel antara 10$15 \%$ atau $20-25 \%$ (Riduwan dan Akdon, 2007: 254). Teknik sampel yang digunakan pada penelitian ini adalah random sampling.

Teknik pengumpulan data yang digunakan dalam penelitian ini, yakni: (1) Angket. Dalam pengumpulan data yang diperlukan, digunakan teknik angket (kuesioner) Menurut Dairi (2013:66) angket (kuesioner) adalah suatu instrument pengumpulan data yang penting dan baku serta sering dipergunakan dalam penelitian. Teknik angket pada penelitian ini digunakan untuk mendapatkan data primer; dan (2) Dokumentasi. Data dalam penelitian kualitatif kebanyakan diperoleh dari sumber manusia atau human resources, melalui observasi dan wawancara. Sumber lain yang bukan dari manusia (non-human resources), diantaranya dokumen, foto dan bahan statistik. Dokumen terdiri bisa berupa buku harian, notula rapat, laporan berkala, jadwal kegiatan, peraturan pemerintah, anggaran dasar, surat-suratresmidan lain sebagainya. Dalam penelitian ini teknik dokumentasi digunakan untuk mengambil data yang bersifat sekunder.

Sedangkan untuk mengolah data yang sudah dikumpulkan, dalam penelitian ini dilakukan langkahlangkah, yakni: (1) Editing, yaitu meneliti semua lembar wawancara satu persatu tentang kelengkapan pengisian dan kejelasannya; (2) Skoring, yaitu member nilai pada setiap data jawaban yang ada dalam angket; (3) Tabulating, yaitu menyajikan hasil dari data yang sudah diberi skor dalam bentuk tabel dan dilengkapi dengan persentasenya; dan (4) Menginput data pada masingmasing tabel analisis data dan menjumlahkannya.

Sebelum penelitian dilaksanakan maka langkah yang utama adalah melakukan uji coba instrumen penelitian. Uji coba dari butir-butir instrumen pada kedua variabel dimaksudkan untuk menguji keabsahan dan kehandalan butir-butir instrumen yang digunakan dalam penelitian. Untuk itu hasil uji coba harus dicari validitas dan realibilitasnya. Uji validitas merupakan uji instrumen data untuk mengetahui seberapa cermat suatu item 
dalam mengukur apa yang ingin diukur. Item dapat dikatakan valid jika adanya korelasi yang signifikan dengan skor totalnya, hal ini menunjukkan adanya dukungan item tersebut dalam mengungkapkan sesuatu yang ingin diungkapkan. Item biasanya berupa pertanyaan atau pernyataan yang ditujukan kepada responden dengan menggunakan bentuk kuesioner (angket) dengan tujuan untuk mengungkap sesuatu (Duwi Priyatno, 2014:51). Dalam penelitian ini validitas instrumen diuji dengan menggunakan bantuan program SPSS 20 dengan metode korelasi product moment.

Instrumen yang reliable adalah instrumen yang bila digunakan beberapa kali untuk mengukur objek yang sama, akan menghasilkan data yang sama. Dalam penelitian ini uji realibilitas instrumen dilakukan dengan internal consistency yaitu mencobakan instrumen sekali saja, kemudian data yang diperoleh dianalisis dengan teknik tertentu. Hasil analisisnya dapat digunakan untuk memprediksi reliabilitas instrumen. Pengujian reliabilitas instrumen dapat dilakukan dengan menggunakan bantuan program SPSS 20. Uji reliabilitas dilakukan dengan menggunakan metode Cronbach Alpha.

Uji Linieritas digunakan untuk mengetahui linieritas data, yaitu apakah dua variabel mempunyai hubungan yang linier atau tidak. Uji ini digunakan sebagai prasyarat dalam analisis korelasi Pearson atau regresi linier. Pengujian pada SPSS 20 dengan menggunakan Test for Linearity pada taraf signifikansi 0,05 . Dua variabel dikatakan mempunyai hubungan yang linier bila signifikansi (Linearity) kurang dari 0,05. Teori lain mengatakan bahwa dua variabel mempunyai hubungan yang linier bila signifikansi (Deviation for Linearity) lebih dari 0,05.
Analisis korelasi pearson atau dikenal juga dengan korelasi product moment adalah analisis untuk mengukur keeratan hubungan secara linier antara dua variabel yang mempunyai distribusi data normal (Priyatno, 2014 : 123).

Untuk menganalisis data tentang hubungan penggunaan media pembelajaran audio visual dengan minat siswa, dan untuk menentukan apakah variabel $\mathrm{X}$ dengan variabel $\mathrm{Y}$ terdapat hubungan yang signifikan, maka peneliti menggunakan rumus korelasi product moment (Asyti Febliza \& Zul Afdal, 2015:156-157) yaitu:

$$
\begin{aligned}
& r_{x y} \\
& =\frac{n\left(\sum X Y\right)-\left(\sum X\right)\left(\sum Y\right)}{\sqrt{\left\{n \sum X^{2}-\left(\sum X\right)^{2}\right\}\left\{n \cdot \sum Y^{2}-\left(\sum Y\right)^{2}\right\}}} \\
& \text { Keterangan: }
\end{aligned}
$$$$
\mathrm{r}_{\mathrm{xy}}=\text { Angka Indeks Korelasi Variabel X }
$$$$
\text { DAN Variabel Y }
$$$$
\mathrm{n} \quad=\text { Jumlah Sampel }
$$

$\sum \mathrm{X}^{2}=$ Jumlah Kuadrat Variabel $\mathrm{X}$

$\sum \mathrm{Y}^{2}=$ Jumlah Kuadrat Variabel Y

$\sum X=$ Jumlah Variabel $\mathrm{X}$

$\sum \mathrm{Y}=$ Jumlah Variabel $\mathrm{Y}$

$\sum X Y=$ Jumlah Perkalian Antara Variabel $\mathrm{X}$ dan $\mathrm{Y}$

Kemudian untuk pengujian signifikansi antara variabel $\mathrm{X}$ dengan variabel $Y$ dilakukan dengan criteria menggunakan $r$ tabel pada tingkat signifikansi 0,05 . Jika nilai positif dan $r_{\text {hitung }}>r_{\text {tabel }}$ maka terdapat hubungan yang signifikan antara variabel $\mathrm{X}$ dan variabel $\mathrm{Y}$, jika $\mathrm{r}_{\text {hitung }}<\mathrm{r}_{\text {tabel }}$ maka tidak terdapat hubungan yang signifikan antara variabel $X$ dan variabel $Y$.

Ketentuan nilai $r$ tidak lebih dari harga $(-1 \leq r \leq 1)$. Maksudnya adalah nilai $r$ terbesar adalah +1 dan nilai $r$ terkecil adalah -1 . Apabila $r=-1$ artinya korelasinya negatif sempurna; $r=0$ artinya tidak ada korelasi; dan $r=1$ artinya korelasinya sangat kuat.

\section{HASIL}

\section{Gambaran Umum SMAN 1 Bangkinang Kota}


SMA Negeri 1 Bangkinang Kota terletak di jantung Ibu Kota Kabupaten Kampar, tepatnya di Jalan Jenderal Sudirman No. 65 Bangkinang Kota.SMA Negeri 1 Bangkinang Kota sebelumnya bernama SMA Swasta Bangkinang didirikan pada tanggal 01 Januari 1963. Selama \pm 2 tahun siswa/i SMA Swasta Bangkinang menumpang belajar di SMP Negeri 1 Bangkinang. Barulah pada tahun 1963 dibangun 3 lokal ruang belajar di Jalan Mayor Ali Rasyid, dekat Sungai Petai yang sekarang dijadikan Panti Putra Muhammadiyah.

Pada tanggal 1 September 1965, SMA Swasta Bangkinang memperoleh status Sekolah Negeri melalui Nomor SK: 96/SK/B/III/65-66 Tertanggal 17 Juli 1965 sekaligus berganti nama menjadi SMA Negeri 307 Bangkinang. Kemudian berturut-turut SMA Negeri 307 Bangkinang berganti nama menjadi SMA Negeri 1 Bangkinang, SMA Negeri 1 Bangkinang, SMU Negeri 1 Bangkinang dan kembali menjadi SMA Negeri 1 Bangkinang dan terpilih menjadi Sekolah Binaan Khusus (Binsus) di Kabupaten Kampar.

Pada awal Tahun Ajaran 2008/2009 melalui program pemerintah yang memperkenalkan adanya Sekolah Bertaraf Internasional (RSBI), SMA Negeri 1 Bangkinang ditunjuk sebagai salah satu sekolah Rintisan Sekolah Bertaraf Internasional (RSBI) di Provinsi Riau. Dengan dicabutnya program RSBI melalui keputusan Mahkamah Konstitusi RI pada tahun 2013 lalu, maka SMA Negeri 1 Bangkinang kembali berstatus SSN (Sekolah Standar Nasional).

Seiiring dengan perjalanan waktu, SMA Negeri 1 Bangkinang melalui Surat Keputusan Kepala Dinas Pendidikan dan Kebudayaan Kab. Kampar (Nomor: 420/P dan K-BP/2256 Tanggal 14 Pebruari 2014) kembali berganti nama menjadi SMA Negeri 1 Bangkinang Kota hingga saat ini.
Dalam rentang \pm 52 tahun usia SMA Negeri 1 Bangkinang Kota, telah banyak torehan prestasi sekolah, guru maupun siswa dibidang akademik dan non akademik yang tentunya mengharumkan nama sekolah di tingkat lokal, regional, nasional dan bahkan internasional. Seluruh torehan prestasi/ penghargaan yang dicapai tersebut merupakan bukti kongkrit bahwa SMA Negeri 1 Bangkinang Kota berkomitmen untuk merealisasikan tujuan pendidikan sebagaimana yang dicita-citakan.

Adapun Visi SMA Negeri 1 Bangkinang Kota adalah: "Mewujudkan sekolah yangunggul, berprestasi, berdaya saing tinggi, berwawasan globaldan lingkungan hidup berdasarkan Iman dan Taqwa serta Ilmu Pengetahuan dan Teknologi." Sedangkan misi SMA Negeri 1 Bangkinang Kota adalah: "Misi untuk merealisasikan visi di atas adalah sebagai berikut: (a) Meningkatkan dan mengembangkan kurikulum 2013; (b) Meningkatkan dan mengembangkan propesionalisme guru dan tenaga pendidik; (c) Meningkatkan standar proses pembelajaran yang bermutu efektif dan efisien; (d) Meningkatkan dan mengembangkan fasilitas pendidikan yang lengkap dan modern berbasis IT; (e) Meningkat standar kelulusan yang mengutamakan Iptek dan Imtaq; (f) Mengembangkan mutu kelembagaan dan manajemen; (g) Mengembangkan standar pembiayaan yang efisien dan efektif; (h) Mengembangkan standar penilaian yang otentik dan berkelanjutan; (i) Menciptakan lingkungan sekolah yang bersih, asri dan nyaman; dan (j) Meningkatkan Imtaq dan akhlak mulia.

Jumlah Guru SMAN 1 Bangkinang Kota Tahun Pelajaran 2015/2016 terdiri dari 71 orang guru, baik yang berstatus PNS, guru bantu Provinsi, guru bantu daerah maupun guru yang berstatus honor pentis. 
Pada Tahun Pelajaran 2015/2016, jumlah total siswa SMAN 1 Bangkinang Kota mencapai 987 orang yang terdiri dari 30 kelas. Rata-rata setiap kelas berisi 33-35 siswa yang merupakan siswa dari jurusan IPA, Bahasa dan budaya dan IPS.

Sarana dan prasaranan SMA Negeri 1 Bangkinang Kota yang berada diatas tanah seluas $16.655 \mathrm{~m} 2$ dengan luas bangunan yaitu $\pm 8.104 \mathrm{~m} 2$ adalah ruang kepala sekolah, ruang wakil kepala sekolah, ruang guru, ruang kelas, berbagai ruangan labor, GOR, gudang, ruang osis, musholla dan lain sebagainya.

$\begin{array}{llr}\text { Hubungan } & \text { Penggunaan } & \text { Media } \\ \text { Pembelajaran Audio Visual } & \text { Dengan } \\ \text { Minat Peserta } & \text { Didik } & \text { Pada }\end{array}$

Pembelajaran Pendidikan Agama Islam Siswa Kelas $X$ SMAN 1 Bangkinang Kota

Dari angket yang telah disebarkan kepada responden untuk siswa yang berjumlah 77 orang yang telah dikembalikan oleh 77 responden. Dalam angket tersebut diberikan lima alternatif jawaban (sangat sering, sering, kadangkadang, kurang, tidak pernah) yang dapat dipilih oleh siswa sesuai dengan pernyataan yang diajukan.

Adapun hasil angket yang diberikan dengan judul hubungan penggunaan media pembelajaran audio visual dengan minat peserta didik pada pembelajaran pendidikan agama islam di SMAN 1 Bangkinang Kota adalah sebagai berikut:

Tabel 1 : Hasil Angket Penggunaan Media Pembelajaran Audio Visual (Variabel X)

\begin{tabular}{|c|c|c|c|c|c|c|c|}
\hline \multirow[t]{3}{*}{ No } & \multirow[t]{3}{*}{ Pernyataan } & \multicolumn{6}{|c|}{ Alternatif Jawaban } \\
\hline & & SS & $\mathbf{S}$ & KK & $\mathbf{K}$ & TP & $\Sigma$ \\
\hline & & $\mathbf{F}$ & $\mathbf{F}$ & $\mathbf{F}$ & $\mathbf{F}$ & $\mathbf{F}$ & $\mathbf{F}$ \\
\hline 1 & $\begin{array}{l}\text { Guruku menyampaikan tujuan dalam } \\
\text { proses pembelajaran dengan media }\end{array}$ & 7 & 20 & 41 & 7 & 2 & 77 \\
\hline 2 & $\begin{array}{l}\text { Guruku memilih dan menetapkan media } \\
\text { sebelum memulai proses belajar } \\
\text { mengajar }\end{array}$ & 10 & 19 & 27 & 17 & 4 & 77 \\
\hline 3 & $\begin{array}{l}\text { Guruku mengarahkan perhatian siswa } \\
\text { pada sebuah materi pelajaran dengan } \\
\text { format Ms.PowerPoint dengan bantuan } \\
\text { LCD Projektor/Infokus sambil } \\
\text { mengajukan pertanyaan kepada siswa } \\
\text { secara satu persatu }\end{array}$ & 7 & 16 & 33 & 13 & 8 & 77 \\
\hline 4 & $\begin{array}{l}\text { Guruku mampu menggunakan media } \\
\text { audio visual dengan bervariasi dalam } \\
\text { pembelajaran }\end{array}$ & 5 & 25 & 27 & 11 & 9 & 77 \\
\hline 5 & $\begin{array}{l}\text { Guruku menjelaskan materi pelajaran } \\
\text { yang ditampilkan dengan Ms. PowerPoint } \\
\text { di depan siswanya }\end{array}$ & 9 & 23 & 27 & 10 & 8 & 77 \\
\hline 6 & $\begin{array}{l}\text { Guruku mampu membuat siswanya } \\
\text { menikmati pelajaran dengan baik }\end{array}$ & 20 & 36 & 17 & 3 & 1 & 77 \\
\hline 7 & $\begin{array}{l}\text { Guruku mampu membuat siswanya } \\
\text { senang dalam proses pembelajaran } \\
\text { dengan baik }\end{array}$ & 18 & 32 & 24 & 2 & 1 & 77 \\
\hline 8 & $\begin{array}{l}\text { Guruku memberikan tugas kepada } \\
\text { siswanya }\end{array}$ & 40 & 23 & 14 & 0 & 0 & 77 \\
\hline 9 & $\begin{array}{l}\text { Guruku melakukan evaluasi terhadap } \\
\text { media yang digunakan }\end{array}$ & 5 & 35 & 27 & 6 & 4 & 77 \\
\hline 10 & Guruku melakukan evaluasi terhadap & 18 & 47 & 11 & 1 & 0 & 77 \\
\hline
\end{tabular}




\begin{tabular}{|c|c|c|c|c|c|c|}
\hline \multicolumn{7}{|l|}{ pembelajarannya } \\
\hline Jumlah & 139 & 276 & 248 & 70 & 37 & 770 \\
\hline $\begin{array}{l}\text { Berdasarkan tabel 10di atas } \\
\text { terlihat bahwa jawaban siswa yang } \\
\text { menyatakan guru PAI sering } \\
\text { menggunakan media pembelajaran } \\
\text { audio visual lebih banyak yaitu 276, ini }\end{array}$ & $\begin{array}{l}\text { mer } \\
\text { pem } \\
\text { yan } \\
\text { yan } \\
\text { pali }\end{array}$ & $\begin{array}{l}\text { injuk } \\
\text { elaja } \\
\text { dapa } \\
\text { men } \\
\text { g sed }\end{array}$ & $\begin{array}{l}\text { In gur } \\
\text { n auc } \\
\text { dilih } \\
\text { ataka } \\
\text { it yait }\end{array}$ & $\begin{array}{l}\text { men } \\
\text { vis } \\
\text { dari } \\
\text { tida } \\
37 .\end{array}$ & $\begin{array}{l}\text { unak } \\
\text { l del } \\
\text { awak } \\
\text { per }\end{array}$ & $\begin{array}{l}\text { media } \\
\text { an baik } \\
\text { siswa } \\
\text { h yang }\end{array}$ \\
\hline
\end{tabular}

Tabel 2 : Hasil Angket Minat ( Variabel Y)

\begin{tabular}{|c|c|c|c|c|c|c|c|}
\hline \multirow[t]{3}{*}{ No } & \multirow[t]{3}{*}{ Pernyataan } & \multicolumn{6}{|c|}{ Alternatif Jawaban } \\
\hline & & SS & $S$ & KK & $\mathbf{K}$ & TP & $\sum$ \\
\hline & & $\mathbf{F}$ & $\mathbf{F}$ & $\mathbf{F}$ & $\mathbf{F}$ & $\mathbf{F}$ & $\mathbf{F}$ \\
\hline 1 & $\begin{array}{l}\text { Saya merasa senang dan suka saat belajar } \\
\text { pendidikan agama islam }\end{array}$ & 55 & 21 & 1 & 0 & 0 & 77 \\
\hline 2 & $\begin{array}{l}\text { Saya mempunyai keinginan yang kuat untuk } \\
\text { belajar pendidikan agama islam }\end{array}$ & 52 & 21 & 4 & 0 & 0 & 77 \\
\hline 3 & $\begin{array}{l}\text { Saya memperhatikan guru ketika } \\
\text { menjelaskan materi pelajaran PAI }\end{array}$ & 43 & 27 & 7 & 0 & 0 & 77 \\
\hline 4 & Saya belajar PAI tanpa ada paksaan & 61 & 10 & 5 & 0 & 1 & 77 \\
\hline 5 & Saya belajar PAI dengan sebaik-baiknya & 47 & 20 & 10 & 0 & 0 & 77 \\
\hline 6 & $\begin{array}{l}\text { Saya mempunyai buku panduan PAI untuk } \\
\text { dipelajari }\end{array}$ & 62 & 11 & 3 & 1 & 0 & 77 \\
\hline 7 & $\begin{array}{l}\text { Saya bertanya jika saya tidak mengerti } \\
\text { ketika guru menjelaskan materi pelajaran } \\
\text { PAI }\end{array}$ & 19 & 36 & 22 & 0 & 0 & 77 \\
\hline 8 & $\begin{array}{l}\text { Saya berusaha untuk menjawab setiap } \\
\text { pertanyaan yang ditanyakan guru ketika } \\
\text { mempelajari materi PAI }\end{array}$ & 17 & 43 & 17 & 0 & 0 & 77 \\
\hline 9 & $\begin{array}{l}\text { Saya merasa rugi ketika saya ketinggalan } \\
\text { penjelasan guru saat mempelajari materi PAI }\end{array}$ & 31 & 28 & 15 & 1 & 2 & 77 \\
\hline 10 & $\begin{array}{l}\text { Saya menyediakan waktu luang untuk } \\
\text { mengulang kembali materi PAI yang sudah } \\
\text { dipelajari disekolah }\end{array}$ & 4 & 25 & 42 & 5 & 1 & 77 \\
\hline 11 & $\begin{array}{l}\text { Saya menyelesaikan dan mengerjakan tugas- } \\
\text { tugas materi PAI yang diberikan oleh guru }\end{array}$ & 45 & 28 & 4 & 0 & 0 & 77 \\
\hline & Jumlah & 436 & 270 & 130 & 7 & 4 & 847 \\
\hline
\end{tabular}

Berdasarkan tabel 2 di atas terlihat bahwa jawaban siswa yang menyatakan sangat sering lebih banyak yaitu 436, ini menunjukkan siswa telah memiliki minat yang sangat tinggi.Dan hanya sebagian siswa yang belum memiliki minat yang dapat dilihat dari jawaban siswa yang menyatakan tidak pernah yang paling sedikit yaitu 4 .

Adapun hasil pengujian validitas dan reliabilitas instrumen dapat dilihat pada rekapitulasi tabel berikut :

Tabel 3 : Hasil Rekapitulasi Validitas Penggunaan Media

Jurnal Al-hikmah Vol. 14, No. 2, Oktober 2017 ISSN 1412-5382 
Pembelajaran Audio Visual (Variabel X)

\begin{tabular}{cccc}
\hline Pernyataan & $\begin{array}{c}\text { Nilai } \\
\text { Probabilitas }\end{array}$ & $\begin{array}{c}\text { Taraf Signifikansi } \\
(\boldsymbol{\alpha}=\mathbf{0 , 0 5})\end{array}$ & Keteragan \\
\hline 1 & $\mathbf{2}$ & $\mathbf{3}$ & $\mathbf{4}$ \\
\hline P1 & 0.000 & 0,05 & Valid \\
\hline P2 & 0.000 & 0,05 & Valid \\
\hline P3 & 0.000 & 0,05 & Valid \\
\hline P4 & 0.000 & 0,05 & Valid \\
\hline P5 & 0.000 & 0,05 & Valid \\
\hline P6 & 0.000 & 0,05 & Valid \\
\hline P7 & 0.059 & 0,05 & Tidak Valid \\
\hline P8 & 0.000 & 0,05 & Valid \\
\hline P9 & 0.000 & 0,05 & Valid \\
\hline P10 & 0.000 & 0,05 &
\end{tabular}

Item dalam instrumen dikatakan valid jika signifikansi $<0,05$, tetapi jika signifikansi $>0,05$ item tidak valid. Berdasarkan tabel 14 di atas, dari 10 pernyataan hanya 1 item pernyataan yang tidak valid. Karena memiliki nilai probabilitas atau signifikansi lebih besar $>0,05$ yaitu item $7,(0,059>0,05)$. Hasil ini diperoleh melalui SPSS 20, dengan demikian dalam penelitian ini hanya menggunakan 9 item pernyataan penggunaan media pembelajaran audio visual.

Kemudian instrumen yang sudah valid diuji kembali dengan menggunakan SPSS 20 untuk mengetahui tingkat reliabilitasnya, di mana item yang masuk pengujian adalah item yang valid saja.

Adapun hasil uji instrumen tersebut dengan menggunakan SPSS 20 adalah sebagai berikut:

Tabel 4: Hasil Uji Reliabilitas Penggunaan Media Pembelajaran AudioVisual (Variabel X)

\begin{tabular}{cc}
\hline \multicolumn{2}{c}{ Reliability Statistics } \\
\hline Cronbach's Alpha & N of Items \\
\hline 0,781 & 9 \\
\hline
\end{tabular}

Sumber data : Olahan data SPSS 20

Berdasarkan tabel 4 di atas, dapat diketahui bahwa seluruh instrumen dinyatakan reliabel. Sesuai dengan teori yang telah dijelaskan pada bab III, sebuah instrumen dinyatakan reliabel jika hasil Cronbach's Alpha menunjukkan angka minimal 0,6 dan nilai Cronbach's
Alpha pada tabel di atas adalah 0,781 dengan kriteria baik (memiliki konsistensi yang tinggi). Hal ini menunjukkan bahwa $0,781>0,6$ sehingga intrumen yang telah diuji dapat digunakan sebagai instrumen penelitian. 


\begin{tabular}{cccc}
\hline Pernyataan & $\begin{array}{c}\text { Nilai } \\
\text { Probabilitas }\end{array}$ & $\begin{array}{c}\text { Taraf Signifikansi } \\
(\mathbf{\alpha}=\mathbf{0 , 0 5})\end{array}$ & Keterangan \\
\hline $\mathbf{1}$ & $\mathbf{2}$ & $\mathbf{3}$ & $\mathbf{4}$ \\
\hline P1 & 0,000 & 0,05 & Valid \\
\hline P2 & 0,000 & 0,05 & Valid \\
\hline P3 & 0,000 & 0,05 & Valid \\
\hline P4 & 0,000 & 0,05 & Valid \\
\hline P5 & 0,000 & 0,05 & Valid \\
\hline P6 & 0,000 & 0,05 & Valid \\
\hline P7 & 0,000 & 0,05 & Valid \\
\hline P8 & 0,000 & 0,05 & Valid \\
\hline P9 & 0,000 & 0,05 & Valid \\
\hline P10 & 0,000 & 0,05 & Valid \\
\hline P11 & 0,000 & 0,05 & Valid \\
\hline S40
\end{tabular}

Sumber data : Olahan data SPSS 20

Item dalam instrumen dikatakan valid jika signifikansi $<0,05$, tetapi jika signifikansi $>0,05$ item tidak valid.

Berdasarkan tabel 5 di atas, dari 11 pernyataan semuanya valid. Karena nilai probabilitas atau signifikansi seluruh item pernyataan $<0,05$. Hasil ini diperoleh melalui SPSS 20, dengan demikian penelitian ini menggunakan 11 item pernyataan minat.

Kemudian instrumen yang sudah valid diuji kembali dengan menggunakan SPSS 20 untuk mengetahui tingkat reliabilitasnya, di mana item yang masuk pengujian adalah item yang valid saja.

Adapun hasil uji instrumen tersebut dengan menggunakan SPSS 20 adalah sebagai berikut :

Tabel 6 : Hasil Uji Reliabilitas Minat ( Variabel Y)

Reliability Statistics

Cronbach's Alpha

$\mathrm{N}$ of Items

.799

Berdasarkan tabel 6 di atas, dapat diketahui bahwa seluruh instrumen dinyatakan reliabel. Sesuai dengan teori yang telah dijelaskan pada bab III, sebuah instrumen dinyatakan reliabel jika hasil Cronbach's Alpha menunjukkan angka minimal 0,6 dan nilai Cronbach's Alpha pada tabel di atas adalah 0,786 dengan kriteria baik (memiliki konsistensi yang tinggi). Hal ini menunjukkan bahwa 0,786 >0,6 sehingga intrumen yang telah diuji dapat digunakan sebagai instrumen penelitian.

Adapun hasil uji linieritas antara variabel $X$ (Penggunaan Media Pembelajaran Audio Visual) dan variabel Y (Minat) dijelaskan dalam tabel berikut:

Tabel 7 : Uji Linieritas

\begin{tabular}{lcc}
\hline \multicolumn{1}{c}{ Data } & $\begin{array}{c}\text { Taraf } \\
\text { Signifikansi }(\boldsymbol{\alpha})\end{array}$ & Signifikansi \\
\hline Linearity & $<0,05$ & 0,014 \\
\hline Deviation for Linearity & $>0,05$ & 0,648 \\
\hline
\end{tabular}



Berdasarkan tabel 7 di atas, dapat diketahui bahwa penggunaan media pembelajaran audio visual memiliki hubungan dengan minat peserta didik. Ini dapat dilihat dari Linearity yang lebih kecil dari 0,05 $(<0,014)$ dan juga Deviation for Linearity yang lebih besar dari $0,05(>0,648)$.

Angket yang telah diperoleh kemudian diolah, dianalisis, dan disimpulkan menggunakan teknik analisis Korelasi Pearson. Teknik Analisis Korelasi Pearson ini digunakan untuk menganalisis data tentang keeratan Hubungan Penggunaan Media Pembelajaran Audio Visual Dengan Minat Peserta Didik di SMAN 1 Bangkinang Kota. Adapun hasil yang diperoleh dari SPSS 20 adalah sebagai berikut :

Tabel 8 : Hasil Analisis Korelasi Pearson antara Penggunaan Media Pembelajaran Audio Visual (Variabel X) Dengan Minat Belajar Siswa (Variabel Y)

\begin{tabular}{llrr}
\hline & \multicolumn{2}{c}{ Korelasi } & \multicolumn{2}{c}{ Minat } \\
\hline \multirow{2}{*}{ Media Audio } & Media Audio Visual & $.284^{*}$ \\
Visual & Pearson Correlation & 1 & .012 \\
& Sig. (2-tailed) & & 77 \\
\multirow{3}{*}{ Minat } & $\mathrm{N}$ & 77 & 1 \\
& Pearson Correlation & $.284^{*}$ & \\
& Sig. (2-tailed) & .012 & 77 \\
\hline
\end{tabular}

*. Correlation is significant at the 0.05 level (2-tailed).

Tabel 8 di atas menyajikan hasil koefisien korelasi Pearson Product Moment antara dua variabel yaitu variabel penggunaan media pembelajaran audio visual (X) dan variabel minat (Y). Berdasarkan tabel tersebut diperoleh nilai probabilitas Sig. (2-tailed) lebih kecil dari 0,05 yaitu $0,000<0,05$, maka Ho ditolak. Artinya ada hubungan yang signifikansi antara penggunaan media pembelajaran audio visual dengan minat siswa. Hasil korelasi ini sekaligus menjawab hipotesis penelitian dan membuktikan secara empiris bahwa ada hubungan penggunaan media pembelajaran

Tabel 9 : Interpretasi Koefisien Korelatif Penggunaan Media Pembelajaran Audio Visual dengan Minat Siswa di SMA Negeri 1 Bangkinang Kota

\begin{tabular}{cc}
\hline Interval Koefisien & Tingkat Hubungan \\
\hline $0,00-0,199$ & Sangat Rendah \\
\hline $0,20-0,399$ & Rendah \\
\hline $0,40-0,599$ & Sedang \\
\hline $0,60-0,799$ & Kuat \\
\hline $0,80-1,000$ & Sangat Kuat
\end{tabular}

Sumber : Sugiyono, 2015:231

audiovisual dengan minat siswa di SMA Negeri 1 Bangkinang Kota.

Kemudian untuk melihat seberapa besar hubungan antara variabel (X) penggunaan media pembelajaran audio visual dengan variabel minat $(\mathrm{Y})$ dapat dilihat dari nilai pearson correlation yaitu sebesar 0,284. Jadi hubungan antara penggunaan media pembelajaran audio visual dengan minat siswa di SMA Negeri 1 Bangkinang Kota sebesar 0,284 . Selanjutnya untuk melihat tingkat hubungan tersebut dapat dilihat pada tabel interpretasi koefisien korelatif berikut :

Jurnal Al-hikmah Vol. 14, No. 2, Oktober 2017 ISSN 1412-5382 

Nilai 0,284 pada interval koefisien korelasi terletak direntang 0,20 - 0,399. Jadi, tingkat hubungan penggunaan media audio visual terhadap minat peserta didik pada pembelajaran pendidikan agama islam siswa kelas $\mathrm{X}$ SMAN 1 Bangkinang Kota berada pada kriteria "rendah".

Berdasarkan dari hasil perhitungan di atas dapat diketahui bahwa hubungan penggunaan media pembelajaran audio visual dengan minat peserta didik pada pembelajaran PAI, berada dalam kategori rendah karena angka 0,28 berada antara 0,20 - 0,399. Untuk dapat memberi interpretasi hubungan itu, maka dapat digunakan pedoman seperti pada tabel 20.

Selanjutnya, untuk menguji signifikasi hubungan yang ditemukan itu berlaku untuk seluruh populasi, maka perlu diuji signifikasi korelasi Product Momen adalah sebagai berikut :

$$
\begin{aligned}
& t=\frac{r \sqrt{n-2}}{\sqrt{1-r^{2}}} \\
& t=\frac{0,28 \sqrt{77-2}}{\sqrt{1-(0,28)^{2}}} \\
& t=\frac{0,28 \sqrt{75}}{\sqrt{1-(0,0784)}} \\
& t=\frac{0,28 \times 8,66}{\sqrt{0,9216}} \\
& t=\frac{2,4248}{0,96} \\
& t=2,5258=2,53 \\
& \text { Harga } t \text { hitung tersebut } \\
& \text { selanjutnya dibandingkan dengan } \\
& \text { harga t tabel. Untuk kesalahan } 5 \% \text { uji } \\
& \text { dua pihak } \mathrm{db}=\mathrm{n}-77 \text {, maka } \\
& \text { diperoleh tabel }=\text { tarif signifikan }(\mathrm{a}) \\
& =0,05 \\
& \mathrm{db}=\mathrm{n}-2 \\
& =77-2 \\
& =75 \\
& \mathrm{t} \text { tabel dengan } \mathrm{db}=75 \longrightarrow 2,000
\end{aligned}
$$

pembelajaran audio visual dengan minat peserta didik pada pembelajaran PAI.

Berdasarkan perhitungan, maka dapat dinyatakan hipotesis alternatif (Ha) yang menyatakan ada hubungan penggunaan media pembelajaran audio visual dengan minat peserta didik pada pembelajaran PAI diterima, dan hipotesis nol (Ho) ditolak. Jadi kesimpulannya, koefisien korelasi antara penggunaan media pembelajaran audio visual dengan minat peserta didik pada pembelajaran PAI sebesar 0,28 adalah signifikan, artinya koefisien tersebut dapat digeneralisasikan atau dapat berlaku pada populasi dimana sampel yang diambil 77 siswa.

Nilai $r$ tabel untuk $n=77$ dengan taraf kesalahan 5\% diperoleh sebesar 0, 227. Karena $r$ hitung lebih besar dari $r$ tabel maka Ha diterima. Sehingga ada korelasi yang signifikan antara penggunaan media pembelajaran audio visual (variabel $\mathrm{X}$ ) dengan minat (variabel Y).

\section{PEMBAHASAN}

Dari hasil data yang diperoleh, ditemukan bahwa faktor penggunaan media pembelajaran audio visual terdapat hubungan dengan minat peserta didik dalam proses belajar mengajar, ini dibuktikan pada tabel 19 Analisis Korelasi Pearson dengan SPSS 20 dan juga pada rumus Korelasi Product Moment yang menyatakan bahwa terdapat hubungan penggunaan media pembelajaran audio visual dengan minat peserta didik sebesar 0,284, sedangkan dengan rumus Korelasi Product Moment sebesar 0,28 jadi baik menggunakan SPSS 20 dan juga Korelasi Product Moment tidak jauh perbedaannya.

Koefisien korelasi antara hubungan penggunaan media pembelajaran audio visual dengan minat peserta didik pada pembelajaran PAI 
sebesar 0, 284 menggunakan SPSS 20 dan 0,28 menggunakan rumus Korelasi Product Moment adalah signifikan, artinya koefisien tersebut dapat digeneralisasikan atau dapat berlaku pada populasi sampel yang diambil 77 siswa (Ha diterima).

Hubungan penggunaan media pembelajaran audio visual dengan minat peserta didik pada pembelajaran PAI berada pada taraf "Rendah" karena akumulasinya jawaban responden berada pada taraf antara 0,20 - 0,399. Taraf kategori ini bisa dilihat pada tabel 20 di atas.

Nilai $r$ hitung sebesar 0,28 dan $r$ tabel untuk $\mathrm{n}=77$ dengan taraf kesalahan 5\% diperoleh sebesar 0,227. Karena $r$ hitung lebih besar dari $r$ tabel ( $r$ hitung > r tabel) maka Ha diterima. Sehingga ada hubungan yang signifikan antara penggunaan media pembelajaran audio visual (variabel $\mathrm{X}$ ) dengan minat (variabel Y).

Sedangkan nilai $t$ hitung sebesar 2,53 dan $t$ tabel adalah 2,000 untuk derajat kebebasan $(\mathrm{dk})=75$. Karena $\mathrm{t}$ hitung lebih besar dari $t$ tabel (t hitung > t tabel) maka Ha diterima. Sehingga ada korelasi yang signifikan antara penggunaan media pembelajaran audio visual (variabel $\mathrm{X}$ ) dengan minat (variabel Y).

Berdasarkan dari keseluruhan analisis data di atas, jelas terlihat bahwa ada hubungan penggunaan media pembelajaran audio visual dengan minat peserta didik pada pembelajaran PAI di SMAN 1 Bangkinang Kota.

\section{SIMPULAN}

Berdasarkan hasil penelitian dan analisis data yang penulis peroleh, maka dapat ditarik suatu kesimpulan bahwa hubungan penggunaan media pembelajaran audio visual terhadap minat peserta didik pada pembelajaran pendidikan agama islam di SMAN 1 179

14, No. 2, Oktober 2017 ISSN 1412-5382 bangkinang adalah 0,284 olahan SPSS danhasil rumus Korelasi Product Moment 0,28 terletak diantara interval 0,20-0,399 berada pada taraf kategori "rendah". Terdapat hubungan yang signifikan antara penggunaan media pembelajaran audio visual dengan minat peserta didik pada pembelajaran pendidikan agama islam di SMAN 1 bangkinang Kota. Hubungan tersebut dinyatakan dengan tingkat korelasi positif, setelah diuji lewat uji signifikansi hasilnya adalah $\mathrm{r}_{\text {hitung }}>\mathrm{r}_{\text {tabel }}(0,28>$ $0,277)$ dan juga $t_{\text {hitung }}>t_{\text {tabel }}(2,53>$ 2,000) sehingga $\mathrm{Ha}$ diterima dan Ho ditolak.

\section{DAFTAR RUJUKAN}

Arsyad, Azhar. 2011. Media Pembelajaran. Jakarta: PT. Raja Grafindo Persada.

Baharuddin. 2007. Psikologi Pendidikan: Refleksi Teoretis Terhadap Fenomena. Jogjakarta: Ar-Ruzz Media.

Dairi, Rizal. 2013. Metodologi Penelitian Berbasis Kompetensi. Pekanbaru: UIR Press.

Daulay, Nurussakinah. 2014. Pengantar Psikologi dan Pandangan AlQur'an Tentang Psikologi. Jakarta: Prenada Media Group.

Djaali. 2007. Psikologi Pendidikan. Jakarta: Bumi Aksara.

Djamarah, Syaiful Bahri dan Zain, Aswan. 2013. Strategi Belajar Mengajar. Jakarta: PT. Rineka Cipta.

Dradjat, Zakiah, dkk., 1995. Metodik Khusus Pengajaran Agama Islam. Jakarta: Bumi Aksara.

Fadlillah, Muhammad. 2014. Desain Pembelajaran PAUD: Tinjauan Teoritik \& Praktik. Jogjakarta: ArRuzz Media.

Febliza, Asyti dan Afdal, Zul. 2015. Statistic Dasar Penelitian Jurnal Al-hikmah Vol. 
Pendidikan. Pekanbaru: Adefa Grafika.

$2015 . \quad$ Media

Pembelajaran dan Teknologi Informasi Komunikasi.

Pekanbaru: Adefa Grafika.

Hamdani. 2011. Strategi Belajar Mengajar. Bandung: Pustaka Setia.

Jahja, Yudrik. 2011. Psikologi Perkembangan. Jakarta: Kencana Prenada Media Group.

Kamus Besar Bahasa Indonesia. 2008. Jakarta: PT. Gramedia Pustaka Utama.

Miarso, Yusufhadi. 2004. Menyemai Benih Teknologi Pendidikan. Jakarta: Kencana.

Prayitno, Duwi. 2014. SPSS 22

Pengolahan Data Terpraktis. Yogyakarta:

Andi Press.

Ridwan dan Akdon. 2007. Rumus dan Data dalam Analisis Statistika. Bandung: Alfabeta.

Rusman, dkk., 2012. Pembelajaran Berbasis Teknologi Informasi dan Komunikasi: Mengembangkan Profesionalitas Guru. Jakarta: Rajawali Pers.

Sanjaya, Wina. 2010. Perencanaandan Desain Sistem Pembelajaran. Jakarta: Kencana.
Sardiman. 2001. Interaksi dan Motivasi Belajar Mengajar. Jakarta: Rajawali Press.

Shaleh, Abdul Rahman. 2008. Psikologi Suatu Pengantar dalam Perspektif Islam. Jakarta: Kencana Prenada Media Group.

Slameto. 2010. Belajar dan Faktor-faktor yang Mempengaruhinya. Jakarta: PT. Rineka Cipta.

Sriyanti, Lilik. 2013. Psikologi Belajar. Yogyakarta: Ombak.

Sugiyono. 2015. Statistika Untuk Penelitian. Bandung: Alfabeta.

Suryani, Nunuk dan Agung, Leo. 2012. Strategi Belajar Mengajar. Yogyakarta: Penerbit Ombak.

Suripah. 2014. Statistika Pendidikan. Pekanbaru: UIR Press.

Sutrisno dan Suherman. 2007. Modul Menggunakan Peralatan Kantor. Sukabumi: Ghalia Indonesia Printing.

Suryabrata, Sumadi. 2005. Psikologi Pendidikan. Jakarta: PT. Raja Grafindo Persada.

Suyono dan Hariyanto. 2015. Implementasi Belajar dan Pembelajaran. Bandung: PT. Remaja Rosdakarya.

Syah, Muhibbin. 2007. Psikologi Belajar. Jakarta: Raja Grafindo Persada. 